\title{
Development of the Polish geothermal sector in the light of current possibilities of financial support for a geothermal investment
}

\author{
Anna Sowiżdżał ${ }^{1}$, Barbara Tomaszewska ${ }^{1}$, and Anna Chmielowska $^{1, *}$ \\ ${ }^{1}$ AGH University of Science and Technology, Faculty of Geology, Geophysics and Environmental Protection, Department of Fossil \\ Fuels, Mickiewicza 30 Avenue, 30-059 Kraków, Poland
}

\begin{abstract}
Geothermal energy is an internal heat of the Earth, that is a prospective and sustainable source of renewable energy. In Poland, despite having significant amount of low-temperature geothermal resources, its share in the national energy mix remains marginal but growing. Currently, the utilisation of geothermal resources is related to hydrogeothermal resources, that are used mainly in space heating, recreation and balneotherapy. Nevertheless, the indication of potential electricity production is under research. The utilisation of geothermal resources entails a plenty of environmental benefits that are particularly important in the context of the present pollution problem. Therefore, the development of the geothermal energy sector is of relevant importance and with appropriate legal and financial conditions it may have a bearing on improvement of the environment's quality and, ipso facto, living in Poland. Thus, this paper presents numerous possibilities of obtaining a financial support for investments in geothermal energy sector. Selected funding and financial backing systems currently available in Poland are discussed. The importance of opportunity of obtaining a financial support for an investment as one of the crucial factors for the geothermal sector development is emphasised. Moreover, the examples of installations implemented in the country in the context of obtained funding are presented.
\end{abstract}

\section{Introduction}

Geothermal energy, as one of the renewable energy resources (RES), is considered clean, environmentfriendly and independent from meteorological conditions. Generally, it is defined as the total amount of thermal energy (internal heat) accumulated inside the Earth, unequally around the globe. The most favorable conditions for the formation, and then occurrence of most prospective geothermal systems are connected to the rift and subduction zones [1]. There, the hightemperature geothermal (i.e. with temperature higher than $150^{\circ} \mathrm{C}$ at $1 \mathrm{~km}$ depth [1]) fields are located. In other cases, the term of low-temperature resources (i.e. temp. below $150^{\circ} \mathrm{C}$ at $1 \mathrm{~km}$ depth [1]) is employed. Conventionally, one can distinguish hydrothermal and petrogeothermal resources [2, 3]. Hydrothermal resources are water and/or steam reservoirs, that are categorized as liquid- or water-dominated respectively. By contrast, petrogeothermal resources are connected with hot dry (hardly dry) rock formation [2] and the utilization system of such a reservoir is called enhanced (engineered) geothermal system (abbr EGS) [4].

The development of the energy sector based on renewable energy sources is an extremely important issue of the energy policy of the European Union Member States [5]. This is due to greater care for the protection of the natural environment, as well as an attempt to diversify internal energy sectors and improve the country's energy security. In 2016, the RES energy mix in Poland consisted mainly of solid biofuels $(70.74 \%)$, wind energy $(11.93 \%)$, liquid biofuels $(10.16 \%)$, biogas $(2.88 \%)$ and water energy $(2.03 \%)$ and other $(2.26 \%)$ [6]. The acquisition of geothermal energy accounted merely for $0.24 \%$ of all energy gained from RES [6]. Until now, the growth of Polish geothermal energy sector has been noticeable but insufficient considering the amount of geothermal resources and their energetic potential. Nevertheless, efforts currently taken by the government and academia might conduce to the intensification of development of geothermal energy sector in Poland [7].

\section{Geothermal energy resources in Poland}

Geological conditions of geothermal resources in Poland have been analyzed since the 80 s of last century and geothermal waters have already found applications in heating, balneotherapy and recreation [8-11]. Those geothermal resources are related to underground waters of different stratigraphic layers (thereby various depths) within four major provinces that are subsequently: the Polish Lowlands, the Carpathians, the Carpathian

\footnotetext{
*Corresponding author: adrabik@agh.edu.pl
} 
Foredeep and the Sudetes (Fig. 1). Generally, they are natural sedimentary-structural basins filled with geothermal waters with relatively high temperature range, namely, from $20^{\circ} \mathrm{C}$ to about $90^{\circ} \mathrm{C}$ (even up to $100^{\circ} \mathrm{C}$ at the depth between $1-4 \mathrm{~km}$ [7]. Generally, the water flowrates (from a single well) vary from several to around $150 \mathrm{dm}^{3} / \mathrm{s}$, whereas the total dissolved solids (TDS) of thermal waters differ from $0.4 \mathrm{~g} / \mathrm{dm}^{3}$ to as many as $300 \mathrm{~g} / \mathrm{dm}^{3}$, depending on the province. The most prospective regions for a geothermal energy development in Poland are connected with areas characterized by a high value of heat flux and appropriate hydrogeological parameters, and are ascribed to the Polish Lowlands and the Podhale region, i.e. the Carpathian Geothermal Province [3].

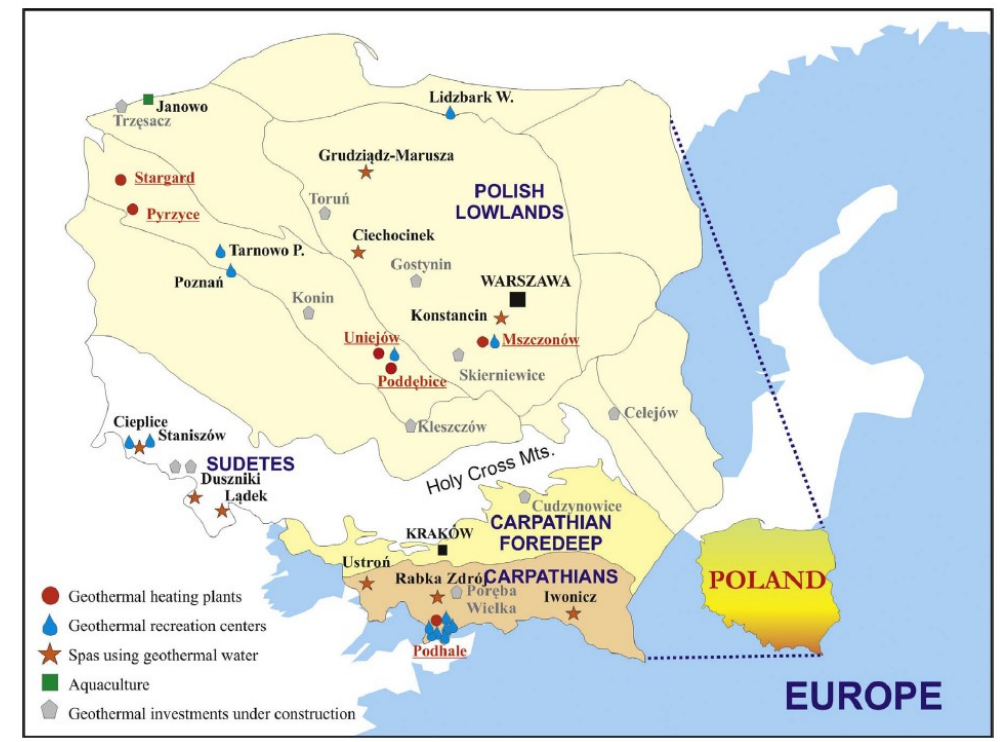

Fig. 1. Geothermal energy provinces and installations in Poland (modificated after [3]).

The Polish Lowlands is the largest (about $87 \%$ of the country) among geothermal fields within the country and it is characterized by the geothermal gradient varying from $2-3^{\circ} \mathrm{C} / 100 \mathrm{~m}$. The highest capacity for a single well is $300 \mathrm{~m}^{3} / \mathrm{h}$, whereas the TDS of thermal waters amounts even to $300 \mathrm{~g} / \mathrm{dm}^{3}$. The major resources of geothermal waters are accumulated within the Mesozoic groundwater horizons - primarily in the Lower Jurassic and Lower Cretaceous formations but significant importance is ascribed also to the Upper Jurassic, Middle Jurassic, Upper Triassic and Lower Triassic formations [8]. Considering the Podhale region, the hydrothermal resources are assembled in the Mesozoic sedimentary formations - the most prospective aquifers occur within the Middle Triassic limestones and dolomites, as well as in overlying Eocene carbonates [3, 12]. The maximum temperature of reservoir is set as $90-95^{\circ} \mathrm{C}$ at the depth between $2-3.2 \mathrm{~km}$, and the (artesian) flow rates varies from several to even $500 \mathrm{~m}^{3} / \mathrm{h}$ for a single well. The TDS of thermal waters are measured as $0.1-3.2 \mathrm{~g} / \mathrm{dm}^{3}$. The Fore-Carpathian Geothermal Province is less prospective in the context of possible utilization in heating but might find the successful application in recreation and/or balneotherapy. In the Carpathian Foredeep, low discharges (several $\mathrm{m}^{3} / \mathrm{h}$ ) of single wells (in vast majority of aquifers) are observed, except from the Cenomanian reservoir (sandstones). In this case, the water capacity is expected to reach even $250 \mathrm{~m}^{3} / \mathrm{h}$ and the temperature of geothermal waters varies from 30 to $100^{\circ} \mathrm{C}$ [3]. The TDS rises from the East to the West of the province, presenting values from $1-150 \mathrm{~g} / \mathrm{dm}^{3}$. Last but not least - the Sudetic Geothermal Province differs from aforementioned areas, as geothermal waters occur only within the crystalline formations. The temperature of geothermal waters vary between 20 and $87^{\circ} \mathrm{C}$, whereas, the average well capacity is about $10 \mathrm{~m}^{3} / \mathrm{h}$. Thus, this province is rather insignificant for a space heating sector, but has an important application in curing and therapeutic issues [12].

Poland is endued with low-temperature hydrothermal resources, thus primary applications involve three fields: space heating, bathing and recreation as well as balneotherapy (Fig. 1). Nonetheless, the geothermal waters are also used in agriculture (e.g. production of pickled cucumbers in Uniejów), aquaculture (e.g. fish farming in Janowo) and for different industrial applications (e.g. production of cosmetics in Poddębice or wood drying in Podhale). In 2018, six geothermal district heating plants were operating: in Podhale region and municipalities of Pyrzyce, Mszczonów, Poddębice, Uniejów and Stargard. The total installed capacity amount to $76.2 \mathrm{MWth}$, which gives production of $868 \mathrm{TJ}$ of geothermal heat [7]. Moreover, 17 recreation centers are located within the country, where geothermal water is used both for swimming pools and other facilities as well as for preparation of hot domestic water. Geothermal water is also utilized in 12 health resorts for curing and rehabilitation purposes. It is worth to be highlighted that numerous projects concerning distinctive geothermal aspects have been under development, including an indication if the utilization of 
existing geothermal potential is feasible and sufficient for electricity production [13-15].

\section{Geothermal energy in the Polish legislation}

Currently, for the successful development of the geothermal energy sector in Poland, it is necessary to introduce a coordinated system of actions, namely the symbiosis of legal and administrative regulations with the simultaneous possibility of obtaining financial support for geothermal investments $[16,17]$.

Generally, Polish legislation regarding the use of energy from renewable sources, including geothermal energy, is strongly determined by the conditioning derived from the European Union [5, 18, 19]. Such regulations allow not only for proceeding the efficient, sustainable exploitation and utilization of geothermal energy, but also urge our country to take the following steps essential for the dynamic development of the broadly understood renewable energy sector. The most important internal legal act that regulates principles of the exploration, recognition and exploitation of geothermal reservoirs is the Geological and Mining Law [20], however, supported by numerous ministerial regulations. An extremely important step for the development of geothermal energy was the introduction of modifications in the Geological and Mining Law, aimed at facilitating the potential entrepreneur to conduct geothermal investments with simultaneous care for the natural environment [21, 22]. The fundamental changes concern the way of obtaining a concessionsince 2012 acquiring the concession has been simplified from 3-stages long (subsequently for exploration, recognition and exploitation) to 1-stage long (only for exploitation) [20]. What is worth noting, the single-step licensing not only makes it easier for a potential entrepreneur to pursue legal and administrative proceedings, but also reduces the related costs. What is more, according to Ministry of the Environment's Announcement, the operating (zero) rate for extracting thermal waters has been maintained [23].

The important factor for the development of the geothermal energy sector in our country is also ongoing work on the strategic document State Resource Policy [24], which began in 2017. The paramount objective of the work is to secure the long-term economic and social needs of the country, resulting from the adopted priorities of Poland's economic development [24]. Geothermal energy was included in the second pillar of the project, i.e. Acquisition of raw materials from mineral deposits and the heat of the Earth [25]. The utilization of thermal water potential for heat production requires the introduction of a stable system for the noncurrent development of geothermal energy sector [25]. The State Resources Policy initiates activities aimed at the compilation of appropriate legal regulations, procedures for the assessment of geothermal installations' projects in terms of: optimal location, rational use of heat resources, avoidance of conflicts of interest and estimation of geological and economic risk
[25]. It is a fundamental document to intensify the development of the geothermal energy sector in Poland [7].

\section{Financial support for a geothermal investment}

The recognition of geothermal energy as one of the Polish Government's priorities in national energy and economic development has translated into the launch of a financial backing programs for geothermal investments, by the Ministry of the Environment [7]. The financial support for the Polish geothermal energy sector is provided mainly by the National Fund for Environmental Protection and Water Management (abbr NEEP\&WM) [26]. The NEEP\&WM is the pillar of the Polish system of financing distinctive projects aimed at effective and efficient environmental protection [26]. In the context of geothermal energy the main goal is set as utilization of geothermal energy resources for heating purposes and generation of electricity, for the period from 2014 to 2025 [26]. Three relevant programs are available for entrepreneurs in case of geothermal energy sector, namely: Geology and Mining - Part 1) Recognition of the geological structure of the country and management of mineral deposits and groundwater resources; Improvement of Air Quality - Part 1) Energy use of geothermal resources; Operational Program Infrastructure and Environment - Activity 1.1. Supporting the production and distribution of energy from renewable sources (co-financed from the Cohesion Fund) [26]. These priority programs of the NEEP\&WM fit into the national energy policy that is aimed at increase the share of RES in the energy mix and promote green energy, including geothermal resources, simultaneously, reducing or even covering the costs of potential geothermal investment.

\subsection{Geology and Mining Program}

The Geology and Mining program - Part 1) Recognition of the geological structure of the country and management of mineral deposits and groundwater resources [26] is aimed at the exploration and recognition of geothermal resources within the country both hydrothermal and petrogeothermal resources. The program is addressed to private entrepreneurs (from micro to large businesses) and territorial self-government units. In this priority program, grant is the form of financing, however its amount depends on the kind of beneficiary. Projects implemented by the territorial selfgovernment units may apply for a subsidy of up to $100 \%$ of eligible costs, whereas enterprises may receive $50 \%$ of eligible expenditure. Nevertheless, there is the possibility to increase the co-financing value for entrepreneurs by $10 \%$, in the case of medium-sized enterprises and by $20 \%$ for small and micro-businesses. The obtainment of the financial backing is conditioned by accomplishment of formalities, submitting an application as well as appropriate documents. The basic conditions that are put before the applicant for the 
financial support from the NEEP\&WM include having an approved Project of Geological Work (consistent with the Geological and Mining Law), analysis of the conditions for the use of geothermal resources and tenure of land. It is also essential to obtain a positive opinion regarding the project issued by the Ministry of the Environment and do not begin the implementation of the geothermal investment before submitting the application for the financial support. Call for proposals is on a continuous basis until 11/30/2018 or when the funds are exhausted.

\subsection{Improvement of Air Quality Program}

The Improvement of Air Quality program - Part 1) Energy use of geothermal resources [26] is aimed at the construction of a new and/or extension of the existing geothermal Heat and Power Plant and District Heating Plant, revitalization of an old borehole as well as drilling an injection well (with the proviso that the construction of the test hole is not possible). In the case of this program, there are two different ways of financial backing, namely, loan or capital investment. The cofinancing in the form of loan can amount to $75 \%$ of eligible costs, while in the case of capital investment it can cover up to $85 \%$ of eligible expenditure. In the first case, the loan can amount to 1-90 million PLN in two forms of lending rate: market conditions or preferential terms (with reserve of maintaining the value not lower than $2 \%$ p.a.). The loan is allocated for a period of 15 years without the possibility of remission. The financial support in the form of capital investment is available only for owners of private limited company or jointstock company. It should be noted that the share of funds raised from the NEEP\&WM should not exceed $49 \%$ of nominal capital. Also, the capital investment ought to transcend 3 million PLN. As in the case of loans, the cofinancing period cannot be longer than 15 years. Call for proposals is on a continuous basis until 12/28/2018.

\subsection{Operational Program Infrastructure and Environment}

Operational Program Infrastructure and Environment Activity 1.1. Supporting the production and distribution of energy from renewable sources [26] comprises the construction of a new geoDH Plant (together with connection to the DH network) or enhancement of thermal power of yet operating geoDH (thermal capacity higher than 2MWth). The chance for getting financial support for electricity production has been excluded. The highest co-financing possible to obtain is $85 \%$ of eligible costs, and single entrepreneur can receive maximally 15 million PLN. Submitted projects are to be evaluated in terms of decrease in the level of carbon dioxide $\left(\mathrm{CO}_{2}\right)$ emission per unit of the financial backing and the economically justified rate of co-financing amount to the obtained capacity. Call for proposals finished in 2017.

Table 1. Geothermal projects financed from the NEEP\&WM funds, within the Geology and Mining Program (based on [7, 26-31]).

\begin{tabular}{|c|c|c|c|c|c|}
\hline & SZAFLARY & $\begin{array}{l}\text { LĄDEK- } \\
\text { ZDRÓJ }\end{array}$ & SOCHACZEW & SIERADZ & KOLO \\
\hline $\begin{array}{l}\text { Subject } \\
\text { matter }\end{array}$ & $\begin{array}{l}\text { Exploitation } \\
\text { of } \\
\text { geothermal } \\
\text { resources }\end{array}$ & $\begin{array}{l}\text { Recognition } \\
\text { and } \\
\text { exploitation of } \\
\text { geothermal } \\
\text { resources }\end{array}$ & $\begin{array}{l}\text { Recognition and } \\
\text { exploitation of } \\
\text { geothermal } \\
\text { resources }\end{array}$ & $\begin{array}{l}\text { Recognition } \\
\text { and } \\
\text { exploitation } \\
\text { of geothermal } \\
\text { resources }\end{array}$ & $\begin{array}{l}\text { Recognition } \\
\text { and } \\
\text { exploitation of } \\
\text { geothermal } \\
\text { resources }\end{array}$ \\
\hline $\begin{array}{l}\text { Planned } \\
\text { scope of } \\
\text { operation }\end{array}$ & $\begin{array}{c}\text { Generation } \\
\text { of electricity; } \\
\text { space } \\
\text { heating }\end{array}$ & $\begin{array}{l}\text { Space heating; } \\
\text { balneotherapy; } \\
\text { agriculture; } \\
\text { and other }\end{array}$ & $\begin{array}{l}\text { Space heating; } \\
\text { drinking water }\end{array}$ & $\begin{array}{c}\text { Space } \\
\text { heating; } \\
\text { balneotherapy }\end{array}$ & $\begin{array}{c}\text { Generation } \\
\text { of electricity; } \\
\text { balneotherapy }\end{array}$ \\
\hline $\begin{array}{l}\text { Depth of } \\
\text { well }\end{array}$ & $5.3 \mathrm{~km}$ & $2.5 \mathrm{~km}$ & $1.4 \mathrm{~km}$ & $1.5 \mathrm{~km}$ & $3.6 \mathrm{~km}$ \\
\hline $\begin{array}{c}\text { Expected } \\
\text { temperature }\end{array}$ & $130^{\circ} \mathrm{C}$ & $80^{\circ} \mathrm{C}$ & $40^{\circ} \mathrm{C}$ & $62^{\circ} \mathrm{C}$ & $100^{\circ} \mathrm{C}$ \\
\hline $\begin{array}{l}\text { Reservoir } \\
\text { formation }\end{array}$ & $\begin{array}{c}\text { Eocene } \\
\text { (nummulite) } \\
\text { and } \\
\text { Mesozoic }\end{array}$ & $\begin{array}{l}\text { Metamorphic } \\
\text { of Lądek and } \\
\text { Śnieżnik }\end{array}$ & $\begin{array}{c}\text { Lower } \\
\text { Cretaceous } \\
\text { (sandstones) }\end{array}$ & $\begin{array}{c}\text { Lower } \\
\text { Jurassic } \\
\text { (sandstones) }\end{array}$ & $\begin{array}{c}\text { Lower Jurassic } \\
\text { and Lower } \\
\text { Cretaceous } \\
\text { (sandstones) }\end{array}$ \\
\hline $\begin{array}{l}\text { Investment } \\
\text { costs }\end{array}$ & 45 M PLN & 19 M PLN & $11 \mathrm{M}$ PLN & 10.6 M PLN & $22.15 \mathrm{M}$ PLN \\
\hline $\begin{array}{c}\text { Financial } \\
\text { support }\end{array}$ & $45 \mathrm{M}$ PLN & 19 M PLN & $11 \mathrm{M}$ PLN & 10.6 M PLN & 22.15 M PLN \\
\hline $\begin{array}{l}\text { Predicted } \\
\text { completion } \\
\text { time (year) }\end{array}$ & 2021 & 2019 & 2020 & 2018 & 2018 \\
\hline
\end{tabular}

\subsection{Effects of Financial Support from the NEEP\&WM}

The rational effect of the programs implemented by NEEP\&WM [26] is the implementation of new geothermal investments and increase in the efficiency of existing installations in Poland.

Until now, 30 applications for the financial support for geothermal investments have been received under the Geology and Mining program, 17 have received a 
positive opinion and 6 of them (towns of Szaflary, Ląek-Zdrój, Sochaczew, Sieradz, Koło, Tomaszów Mazowiecki) have signed agreements with NEEP\&WM, the others are still waiting for the decision of the Main Geologist of the Country. The five aforementioned beneficiaries were given acceptance and financial support covering $100 \%$ of eligible costs - summarily 107 million PLN. Among the approved geothermal investments (Tab. 1), there are projects aimed at the realization of: research and exploitation borehole Bańska PGP-4 (Szaflary), explorative well Koło GT-1 (Chojny), exploratory well LZT-1 (Lądek-Zdrój), explorative borehole Sochaczew GT-1 (Sochaczew) as well as recognition and documentation of thermal water resources in Sieradz.
Within the program implemented by the National Fund for Environmental Protection and Water Management and financed from the Cohesion Fund, a positive evaluation were given to 14 projects - 9 of them were recommended for obtaining a financial support, including 4 concerning the utilization of geothermal energy. This group of beneficiaries includes Geotermia Torun with the project Construction of a geothermal DH plant in Torun using the existing TG-1 and TG-2 wells, Geotermia Podhalańska which plans to increase the operating capacity, G-Term Energy with application for proceeding geothermal wells' drilling (4 pcs.) in Stargard and the last project concerning the extension of the Bania tourist complex together with the construction of a geothermal DH plant (Tab. 2).

Table 2. Geothermal project co-financed from the NEEP\&WM within the Operational Program Infrastructure and Environment (based on [7, 26, 27, 32, 33]).

\begin{tabular}{|c|c|c|c|c|}
\hline & $\begin{array}{c}\text { GEOTERMIA } \\
\text { TORUŃ }\end{array}$ & $\begin{array}{c}\text { GEOTERMIA } \\
\text { PODHALAŃSKA }\end{array}$ & $\begin{array}{l}\text { G-TERM } \\
\text { ENERGY }\end{array}$ & $\begin{array}{l}\text { BANIA TOURIST } \\
\text { COMPLEX }\end{array}$ \\
\hline Town/Region & Toruń & Podhale & Stargard & Białka Tatrzańska \\
\hline Subject matter & $\begin{array}{l}\text { Construction of } \\
\text { a geoDH plant, } \\
\text { connection to the } \\
\text { distribution grid }\end{array}$ & $\begin{array}{l}\text { Extension of the } \\
\text { geothermal system } \\
(+10 \mathrm{MWth})\end{array}$ & $\begin{array}{c}\text { Geothermal wells' } \\
\text { drilling } \\
\text { (4 boreholes) }\end{array}$ & $\begin{array}{l}\text { Construction of } \\
\text { a geoDH plant, with } \\
\text { pipelines and } \\
\text { distribution } \\
\text { equipement }\end{array}$ \\
\hline $\begin{array}{c}\text { Planned scope of } \\
\text { operation }\end{array}$ & $\begin{array}{l}\text { Space heating; } \\
\text { balneotherapy }\end{array}$ & Space heating & Space heating & Space heating/cooling \\
\hline Investment costs & $40.3 \mathrm{M}$ PLN & $32.7 \mathrm{M}$ PLN & - & - \\
\hline Financial support & $19.5 \mathrm{M}$ PLN & $12.2 \mathrm{M}$ PLN & 40.1 M PLN & $2.1 \mathrm{M}$ PLN \\
\hline
\end{tabular}

\section{Conclusion}

Geothermal energy, being one of RES, is considered clean, abundant and reliable source of energy that can be utilized in numerous manners - heat and electricity production, recreation, balneotherapy and various industrial applications. Poland, besides being endowed with low-temperature $\left(<150^{\circ} \mathrm{C}\right)$ geothermal resources, geothermal energy is a marginal contributor to the national energy mix $(0.24 \%)$. Nevertheless, due to the implemented changes within the internal legislation (i.e. the Geologic and Mining Law, the State Resources Policy) and introduction of financial support (provided by the National Fund for Environmental Protection and Water Management, abbr NEEP\&WM) for geothermal investments, the increased development of the geothermal energy sector can be observed. So far, financial support from the NEEP\&WM - within programs Geology and Mining (Part 1) and Operational Program Infrastructure and Environment, has been allotted to 10 beneficiaries, among which there are communes: Szaflary, Koło, Lądek-Zdrój, Sochaczew, Sieradz, Tomaszów Mazowiecki and investors: Geotermia Toruń, Geotermia Podhalańska, G-Term Energy and Bania tourist complex. The total amount of currently granted funding exceeds 180 million PLN.

The increase in the utilization of geothermal energy resources and technologies' development might help to fulfill important economic, environmental and social objectives in Poland. It can also reduce the dependence on fossil fuels, providing the country with the energy security and conducing to the diversification of internal energy resources. What is more, geothermal energy resources might be an efficient way for the sustainable development of our country with simultaneous economic growth.

\section{Acknowledgement}

Publication supported by the Polish Ministry of Science and Higher Education as a part of the program of activities disseminating science from the project „Organization of the First International Science Conference - Ecological and Environmental Engineering”, 26-29 June 2018, Kraków.

The paper has been prepared under the AGH-UST research grant No. 11.11.140.031 and grant No. 15.11.140.189.

\section{References}

1. W. Górecki (ed.), et. al. Atlas of geothermal resources of Mesozoic formations in the Polish Lowlands. Ministry of the Environment, ZSE AGH, Kraków, (2006)

2. D.W. Brown, C.V. Duchane, G. Heineken, V.T. Hriscu, The Enormous Potential of Hot Dry Rock Geothermal Energy. [In:] Mining the Earth's Heat: 
Hot Dry Rock Geothermal Energy, Springer Science \& Business Media, pp. 17-44 (2012)

3. A. Sowiżdżał, Renew Sust Energ Rev 82, pp. 40204027 (2018)

4. P. Olasolo, M.C. Juárez, M.P. Morales, S. D’Amico, I.A. Liarte, Renew Sust Energ Rev 56, pp. 133-144 (2016)

5. Directive 2009/28/EC of the European Parliament and of the Council of 23 April 2009 on the promotion of the use of energy from renewable sources and amending and subsequently repealing Directives 2001/77/EC and 2003/30/EC

6. K. Beret-Kowalska, J. Kacprowska, I. Moskal, D. Piwko, A. Jurgaś, Energy from renewable energy sources in 2016. Statistics Poland, Warszawa (2017) (in Polish with English summary)

7. B. Kępińska, Geological Exploration Technology, Geothermal Energy, Sustainable Development 1, pp. 11-28 (2018)

8. W. Górecki, A. Sowiżdżał, M. Hajto, A. Wachowicz-Pyzik, Environ Earth Sci 74, 12, pp. 7487-7495 (2015)

9. M. Miecznik, A. Sowiżdżał, B. Tomaszewska, L. Pająk, Geologos 21, 3, pp. 187-196 (2015)

10. W. Bujakowski, B. Tomaszewska, M. Miecznik, Renew Energ 99, pp. 420-430 (2016)

11. A. Sowiżdżał, M. Kaczmarczyk, Geol J 51, pp. 6576 (2016)

12. Kępińska B. Geothermal Energy Use - Country Update for Poland, 2013-2015. EGC Proceedings, Strasbourg, France (2016)

13. W. Bujakowski, B. Tomaszewska (ed.), Atlas of the possible use of geothermal waters for combined production of electricity and heat using binary Systems in Poland. MEERI PAS, Kraków: (2014)

14. A. Wójcicki, A. Sowiżdżał, W. Bujakowski, Ocena potencjału, bilansu cieplnego i perspektywicznych struktur geologicznych dla potrzeb zamkniętych systemów geotermicznych (Hot Dry Rocks) w Polsce. Ministry of the Environment (2013) (in Polish)

15. M. Kaczmarczyk, Analiza i ocena możliwości produkcji energii elektrycznej przy wykorzystaniu energii cieplnej zakumulowanej w wodach geotermalnych na obszarze województwa małopolskiego. PhD Thesis (2017) [Available In:] The Main Library of AGH-UST (in Polish; not published)

16. M. Mackiewicz, Energia geotermalna, a bezpieczeństwo energetyczne Polski - ujęcie prawne, [In]: P. Kwiatkiewicz,, Bezpieczeństwo energetyczne, rynki surowców i energii teraźniejszość i przyszłość, pp. 289- 305 (2014) (in Polish)

17. A. Kasztelewicz, Geological Exploration Technology, Geothermal Energy, Sustainable Development 1, pp. 173-183 (2016)
18. The National Action Plan on renewable energy sources - Krajowy Plan Działania w zakresie energii ze źródeł odnawialnych. Ministry of Economy, Warszawa (2010)

19. The Energy Policy of Poland until 2030 - Polityka energetyczna Polski do 2030 roku. Ministry of Economy, Warszawa (2010)

20. The Geologic and Mining Law - Prawo Geologiczne i Górnicze (Journal of Laws 2017 item 2126) (in Polish)

21. B. Tomaszewska, G. Hołojuch, Biuletyn PIG 448, 2 , pp. 281-284 (2012) (in Polish with English abstract)

22. A.Sowiżdżał, B. Tomaszewska, A. Drabik, E3S Web Conf 22 (2017)

23. Ministry of the Environment's Announcement Obwieszczenia Ministra Środowiska w sprawie stawek opłat na rok 2018 z zakresu przepisów Prawa geologicznego i górniczego (Journal of Laws 2017 item 868) (in Polish)

24. State Resource Policy - Polityka Surowcowa Państwa [Online:] http://psp.mos.gov.pl/ last access:11/15/2018

25. Second Pillar of State Resource Policy - Polityka Surowcowa Państwa Drugi Filar [Online:] https://www.pgi.gov.pl/dokumentyprzegladarka/psp/5688-filar-b5-cieplo-flayersb5/file.html last access: $11 / 15 / 2018$

26. National Fund for Environmental Protection and Water Management (abbr NEEP\&WM) [Online:] https://www.nfosigw.gov.pl/ last access: 11/15/2018

27. The Geotermia Podhalańska website [Online, last access 11/15/2018:] http://geotermia.pl/funduszeunijne-nasze-projekty/

28. The website of Lądek-Zdrój town [Online, last access:

11/15/2018:]

http://klodzko.naszemiasto.pl/tag/geotermia-ladekzdroj.html

29. The website of Sochaczew town [Online, last access 11/15/2018:] https://e-ochaczew.pl/tag/geotermia-sochaczew

30. The website of Sieradz town [Online, last access 11/15/2018:] http://sieradz.naszemiasto.pl/tag/geotermiasieradz.html

31. The website of Koło town [Online, last access 11/15/2018:] https://www.ekolo.pl/tag/geotermia-w-kole.html

32. The website of Geotermia Torun [Online, last access 11/15/2018:] http://geotermiatorun.pl/pdf/cieplownia.pdf

33. The Bania Tourist Complex website [Online, last access 11/15/2018:] http://hotelbania.pl/ue 